\title{
RWANDA: PLANNED RECONSTRUCTION FOR SOCIAL QUALITY
}

\section{ABSTRACT}

Rwanda is a case-study of social engineering for quality of life (QoL) and demonstrates both the possibilities and the problems that can emerge. What governments do determines the ‘social space’ for QoL. The 1994 Genocide destroyed Rwanda's physical and social infrastructure along with a million or more of its inhabitants. The post-Genocide Government aims to improve quality of life while ensuring that genocide never happens there again. One of the poorest countries in Africa, Rwanda has moved towards developing a viable market economy and expanding GDP to fund poverty alleviation, though more slowly than it would have liked. Beyond this, laws and policies have been promulgated to create work, improve health, empower people through education, embed them in their communities and the nation and in general build social cohesion and inclusion - with considerable success, considering the low starting point. Central to the new Rwanda, however, is building new Rwandans capturing the hearts, minds and loyalty of a previously divided people. The aim is a population which is prepared to put self aside and work collectively for the nation, governed in a spirit of 'dialogue and consensus' rather than opposition and negotiation. However, in practice this amounts to taking totalitarian control over the discursive agenda, which is not necessarily a stable situation. Looking at current outcomes with regard to QoL, the population do not appear to be happier or more satisfied than those elsewhere, and a nontrivial minority would list civil/political empowerment as more important than improving their material conditions. 


\section{INTRODUCTION: RECONSTRUCTING RWANDA}

In a hundred days of 1994 the majority Hutu fraction in Rwanda killed at least 800,000 of the Tutsi, along with Hutu who opposed the slaughter and some of the Twa (indigenous huntergathers), in the Genocide against the Tutsi. The result was the near destruction of the nation. Many people fled the country, GDP plummeted, agriculture was disrupted, food ran short, the schools and hospitals were looted or demolished. The Genocide constituted a total systemic breakdown of governance and of the norms and values that provide the basis for a shared life. Rwanda's history since then has been a story of recovery led by its Government and grounded in a dominant discourse of service to the nation on the part of both Government and citizens.

This chapter looks at Rwanda's reconstruction as an example of social engineering conducted to enhance quality of life (QoL). It illustrates the proposition - which underlies sociological approaches to QoL such as the Social Quality Model (Beck et al 1997, 2001, van der Maesen and Walker 2012) and the Decent Society Model (Abbott et al 2016) - that improving life conditions for a population is not something individuals can do alone but requires an effective economy, a strong and consistent regulatory infrastructure and a collectivist discursive framework of norms and expectations which favours cohesion and social inclusion as well as individual empowerment.

We show that even impoverished states - and Rwanda is still one of the poorest - can provide many of these conditions. However, when social engineering works at the level of normative discourse as well as on material and regulatory conditions, seeking to change the way its citizens understand their world, it becomes totalitarian in the sense of seeking to control how people think as well as what they do. Such control can work against QoL and is very difficult to put aside once undertaken. 
Our sources of evidence for what has been achieved include some of the many national surveys which the National Institute of Statistics of Rwanda (NISR) carries out periodically, following a sampling pattern which incorporates random selection of households and respondents within quotas to ensure accurate geographical and demographic representation. They all have substantial sample sizes and are carried out by trained interviewers under NISR direction and quality control. We mostly use the Integrated Household and Living Conditions Survey (EICV - the acronym dates from the original French name), the Rwandan Labour Force Survey (RLFS) and the Rwandan Demographic and Health Survey (RDHS). From outside Rwanda we have used international time-series data: the World Bank's World Development Indicators (WDI) and Worldwide Governance Indicators (WWGI) and OECD sites for informant on government revenues and development aid. Mostly we have analysed the microdata ourselves or extracted data from published time series, and the 'source reference' will be simply to the source's acronym (e.g. EICV, OECD); the Sources of Data section of the Reference List gives a URL from which they can be accessed.

The case of Rwanda shows how a destroyed society can be rebuilt and QoL enhanced but also that social engineering for this purpose may come at a price.

\section{SOCIAL QUALITY AND THE DECENT SOCIETY}

The conceptual framework of the chapter is the Decent Society Model (Abbott et al 2016). QoL is what people experience. Social is the extent to which a society provides the material, economic and discursive infrastructure to facilitate QoL The Decent Society Model focusses more precisely on the level of the nation state and government planning for change. The model's four inter-related quadrants are illustrated in Figure 1 in the Rwandan context. 
Figure 1: Social Quality in the context of Rwanda

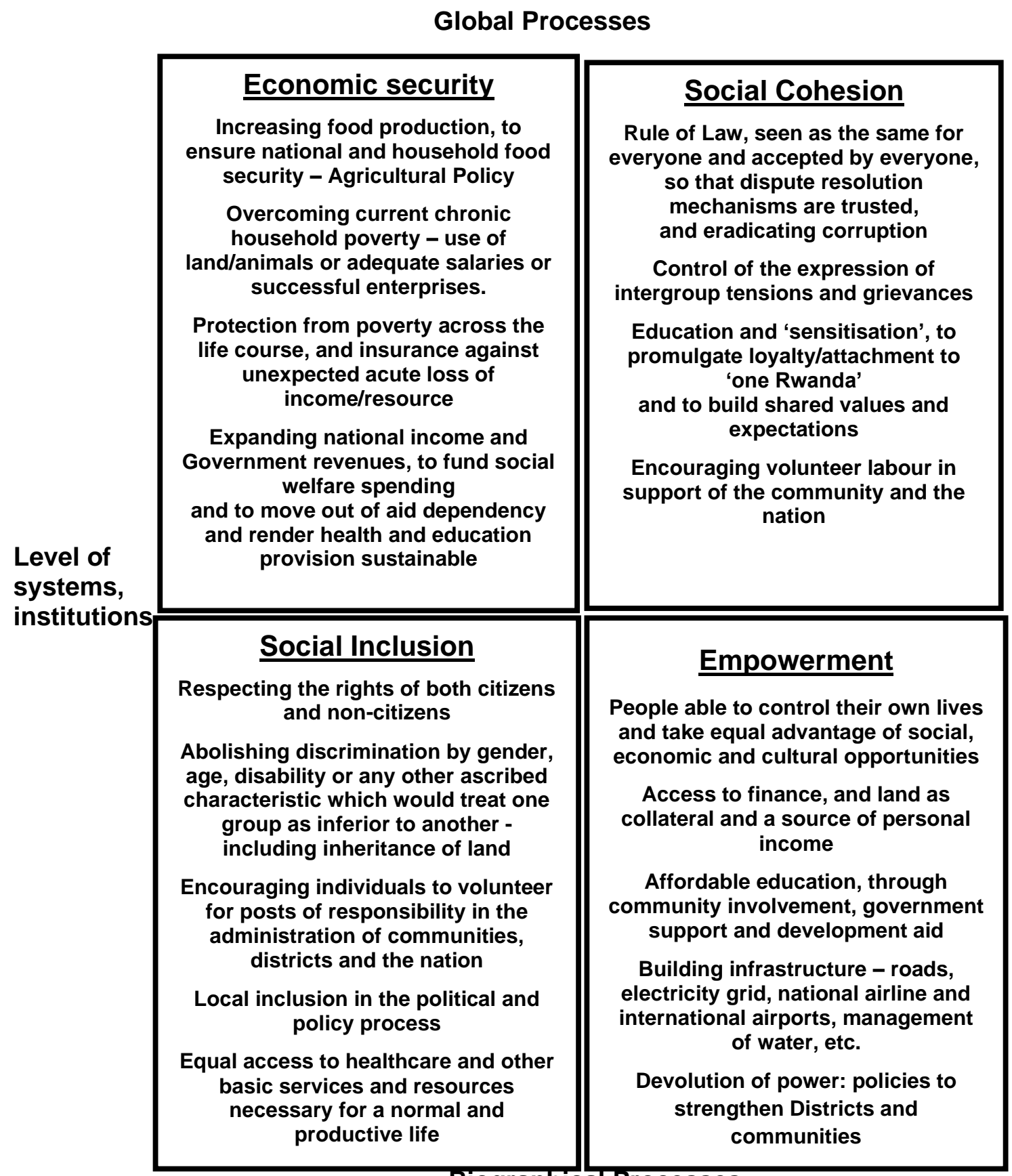

Source: adapted from Abbott et al (2016)

Biographical Processes

Level of communities, groups, individuals

The four quadrants do not assume a fixed causal order but display multiple and even recursive connections, and the allocation of an aspect of life to one quadrant or another is to some extent arbitrary. For example, Economic Security is fundamental for individuals, households and communities - none of the rest is possible when life is from hand to mouth but cohesion, inclusion and particularly empowerment enhance the ability of individuals to 
contribute to the national income. Money (or land and animals) provides for the security of the individual and the community, but it is also an element in social inclusion - the poor are excluded from activities available to the more affluent - and gross disparities tend to make social cohesion much looser.

- Economic Security, in the Decent Society Model, applies to both individuals and the nation state. Individuals need sufficient resource to feed, house and clothe themselves and their household, and they need to know that they will survive the expensive lifestages - in Rwanda particularly child-rearing and old age. Beyond this they need sufficient surplus to cover them during the less productive parts of the year agriculture is seasonal - to insure against loss of employment and to deal with sudden emergencies such as ill health. At the national level sufficient resources are needed for welfare services to be affordable and sustainable.

- Social Inclusion is a self-explanatory concept: the decent life depends on good relations between fractions of the population, which must not feel that they are losing a competition for resource or being treated as less than full citizens, and there must be trust in dispute-resolution procedures and in the willingness of all parties to follow them. There is an economic dimension to this quadrant: those who are in poverty are socially excluded - not free to follow the pattern of life which others take for granted, including participation in politics.

- Social Cohesion is the 'one Rwanda' concept - that the primary self-definition is in terms of equal citizenship, not membership of a group which is favoured or disfavoured in terms of inclusion and/or empowerment. Its discursive extension is into regarding other groups as 'like me' rather than 'the Other' and taking some responsibility for the well-being of outgroups as well as one's own. A fundamental 
element is the Rule of Law - the belief that the same rules fall upon everyone equally - and the eradication of corruption is important for the same reason.

- Individuals are empowered - education is an important means - to develop capabilities, but they exercise them through state-provided infrastructure - healthcare provision, physical infrastructure, internal safety and external security - in general, a well-regulated set of systems which makes what is needed available and regulates disputes . An important element is political empowerment - the extent to which individuals or groups can contribute to the making of policy and influence the division of resources and opportunities, which in turn entails the capability on the part of Government to tolerate dissent, free expression, freedom of association and even freedom to protest (peacefully), in areas central to the Government's vision for the country. This is the core of liberal ideology, such civil/political rights were among the first to be be declared in United Nations Conventions and they are seen as self-evidently desirable in the developed North and West. Their value may not be as obvious, however, in countries where internal dissent has led to catastrophic events such as the Genocide against the Tutsi.

\section{BUILDING SOCIAL QUALITY IN POST-GENOCIDE RWANDA}

After the Genocide and the 'liberation' by the Rwandan Patriotic Front (RPF), Rwanda quickly passed out of explicit military rule and rebuilt itself as a presidential republic with a strong central government and a parliament. The economic stance and 'political settlement' of the RPF, the party which has been in power since the first post-Genocide elections in 2003, involves long-term investment in the future lives of the population - 'developmental neopatrimonialism' (Booth and Golooba-Mutebi, 2012). The problem the RPF were trying to solve by assurances of improvement in QoL was a matter of collective; the policies for reconstruction, including economic policies, were driven by the need to prevent another genocide and were about creating a national identity rather than an ethnic one, through a 
reduction in socioeconomic inequalities - pro-poor policies and more recently inclusive growth, along with gender equality.

In what follows we outline what the Rwandan Government has done to implement this programme. Its commitment to a developmental neopatrimonialist political settlement reproduces many of the elements of the Social Quality Model. as is evident even in the first Constitution after the Genocide, which announces major elements of Social Inclusion, Empowerment and Social Cohesion as fundamental principles:

\section{Article: 9}

The State of Rwanda commits itself to conform to the following fundamental principles and to promote and enforce the respect thereof:

- fighting the ideology of genocide and all its manifestations; - eradication of ethnic, regional and other divisions and promotion of national unity;

- equitable sharing of power;

- building a state governed by the rule of law, a pluralistic democratic government, equality of all Rwandans and between women and men ..

- building a State committed to promoting social welfare and establishing appropriate mechanisms for ensuring social justice;

- the constant quest for solutions through dialogue and consensus.

(Government of Rwanda 2003)

By Article 87 the Senate (the upper house of Parliament) is tasked with supervising the application of all these principles.

Despite the use of the Social Quality/Decent Society framework, our exposition is not neatly divided into its quadrants, because any given policy or law has multiple aims and multiple effects across the quadrants. The descriptive material is divided into three broad subsections: 
- The Rwandan economy (the attempted shift to more labour-efficient agricultural production, building an expanding market economy and creating decent non-farm jobs - in the first instance a matter of Economic Security but also essential for funding the institutional provisions intended to foster improvement in the other three quadrants);

- Welfare and the social wage (poverty alleviation, social protection against seasonally nonproductive periods, vulnerable life-stages and unexpected crises, and the education and healthcare systems as part of the 'social wage' - core elements of provision for Social Inclusion and Social Cohesion, but with implications for empowerment as well);

- Cohesion, Empowerment and Governance (which looks more broadly at the underlying ideological/discursive framework of Rwandan political thought and how cohesion is produced and maintained through communitarian involvement).

\section{The Rwandan Economy}

Inevitably, the economy has been an early and continuing target of intervention - for the country to survive at all as an entity, and to resource the provision of decent lives for all citizens. Rwanda's developmental plans were encapsulated in Vison 2020 (Rwandan Ministry of Finance and Economic Planning 2000), which envisages the transformation of the country from an economy dependent mainly on subsistence agriculture and modest exports of agricultural products and minerals to a modern market and service economy. The plan has been that those who remain in agriculture should become more efficient and produce sufficient to feed Rwanda and generate a surplus for export. At least $50 \%$ of workers would be employed outside agriculture - perhaps adding value to exports of food or minerals, perhaps manufacturing goods for export or to deflect imports), perhaps developing tourism (one of Rwanda's intangible but strong 'natural resources'), but to a substantial extent imitating the success of Singapore and leapfrogging manufacturing to move directly to a 'knowledge economy' and employment in the service sector. Immediate targets for planning and investment have been (a) the modernisation of agriculture, (b) building a private 
industrial/commercial sector, (c) expanding the cultural/conference tourism sector and (d) giving Rwanda a role as a knowledge hub for Africa. This was to be underpinned by building human capital through education. At the same time, economic security was to be procured inclusively by insuring against risk through health and social security provision, and more generally (e) offering good governance dominated by the Rule of Law.

\section{Agricultural policy}

Although the pre-Genocide vision of the peasant economy was rejected (see Verwimp 2013), agriculture and the land remain the essential core of economic security for the majority of Rwandans. The most recent Integrated Household and Living Conditions Survey (EICV5), shows over $70 \%$ of households as still dependent solely or mainly on it and just over $90 \%$ of households as deriving some of their 'income' from it.

Traditional farming has left the land over-exploited, under-fertilised and liable to erosion. Farming is also unproductive in the sense of farmers being under-employed - they say they usually work an average of only 13.2 hours per week (RLFS 2018). To increase the proportion who do not work on the land and still generate agricultural surpluses for internal sale and export, farming had to become more labour-efficient - farmers needed to pursue agriculture as a full-time job. Beyond this the aim was to increase productivity by introducing modern farming - improved seed, chemical fertilizers and insecticides, with the introduction of modern equipment (e.g. tractors) as an eventual aim. Farmers were to rethink their activity as one of growing crops for sale on the market rather than producing primarily for subsistence and selling any surplus.

The successive Agricultural Policies and Strategies have subsidised the improvement of land quality, the introduction of new varieties of crop that thrive in Rwanda, the direction of effort towards growing 'officially approved' crops judged to be needed and saleable on the internal or external market and the consolidation of the traditional small dispersed plots into larger 
farmable areas. (Rwanda did not remove people from their land but it induce/incentivise farmers with adjacent plots to farm them jointly.) Additional measures have been irrigation, terracing, tree-planting and the provision of extension services and post-harvest handling and marketing services. (The eventual mechanisation of farming was part of the plan, but there is little evidence yet of any having taken place.)The main strategy for improving agricultural productivity is the Crop Intensification Programme (CIP) launched in 2007, to which land consolidation was added in 2008. Farmers who obey the instruction to consolidate their land and grow a priority crop as directed by the District are provided with subsidised improved seeds and chemical fertilisers for one planting; thereafter they are expected to purchase fertilizer and seeds from the profit, they make (Kathiresan 2011).

It is not clear, however, that any element of the programme except perhaps land consolidation and the associated direction on what to grow has had any sustained impact on productivity. There is no evidence, for example, that GDP per capita increased as a result of the introduction of the CIP in 2007-8; it has increased steadily over the whole of this century (Figure 2). The rate of increase went up noticeably between 2007 and 2008 (Figure 3), against the general sub-Saharan trend, but it fell even more noticeably in the following year. Further, the programme has not become self-sustaining. The use of improved inputs may increase yields, but farmers generally use them only when they are subsidised (USAID Land Project 2014). The increase in priority crops on local markets brings down the price, so income from the surplus is not seen as sufficient to purchase fertilizer and improved seeds (Abbott and Malunda 2014) while also feeding the family, paying health insurance for all of them and sending the children to school. 


\section{Figure 2: GDP per capita (constant 2011 \$ppp)}

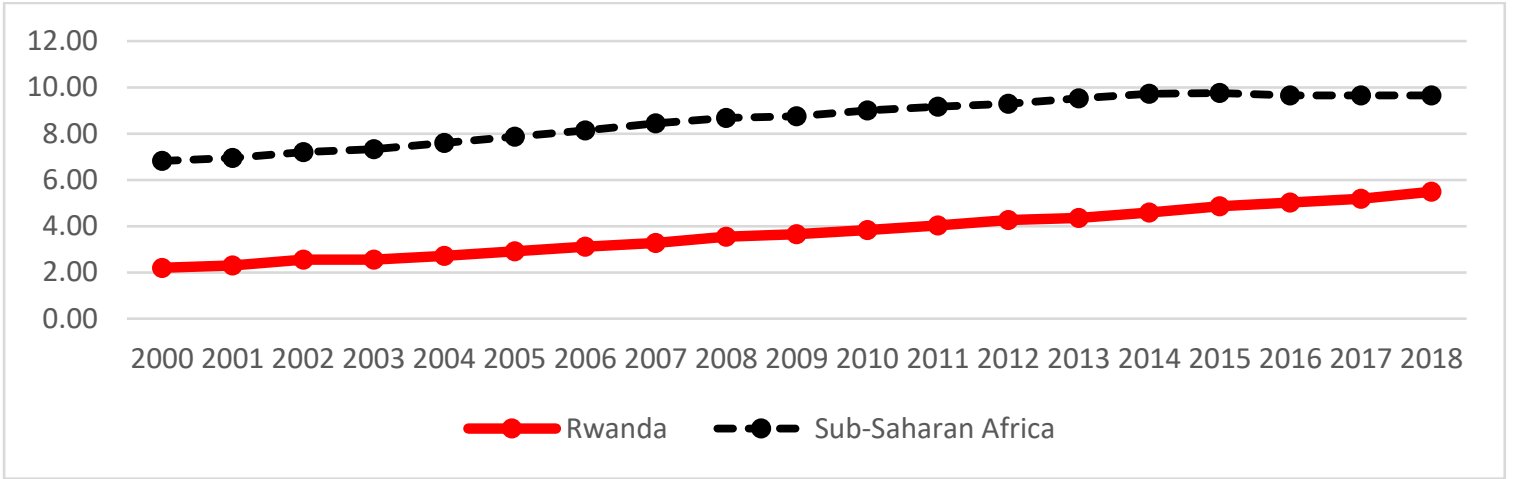

Source: World Bank (WDI). Note: the figures control for population growth, fluctuation in exchange rates and differences in incountry purchasing power. The international poverty line is set as $\$ 1.90$ per day.

Figure 3: Annual rate of GDP growth per Capita in Rwanda and Sub-Saharan Africa $(\%)$

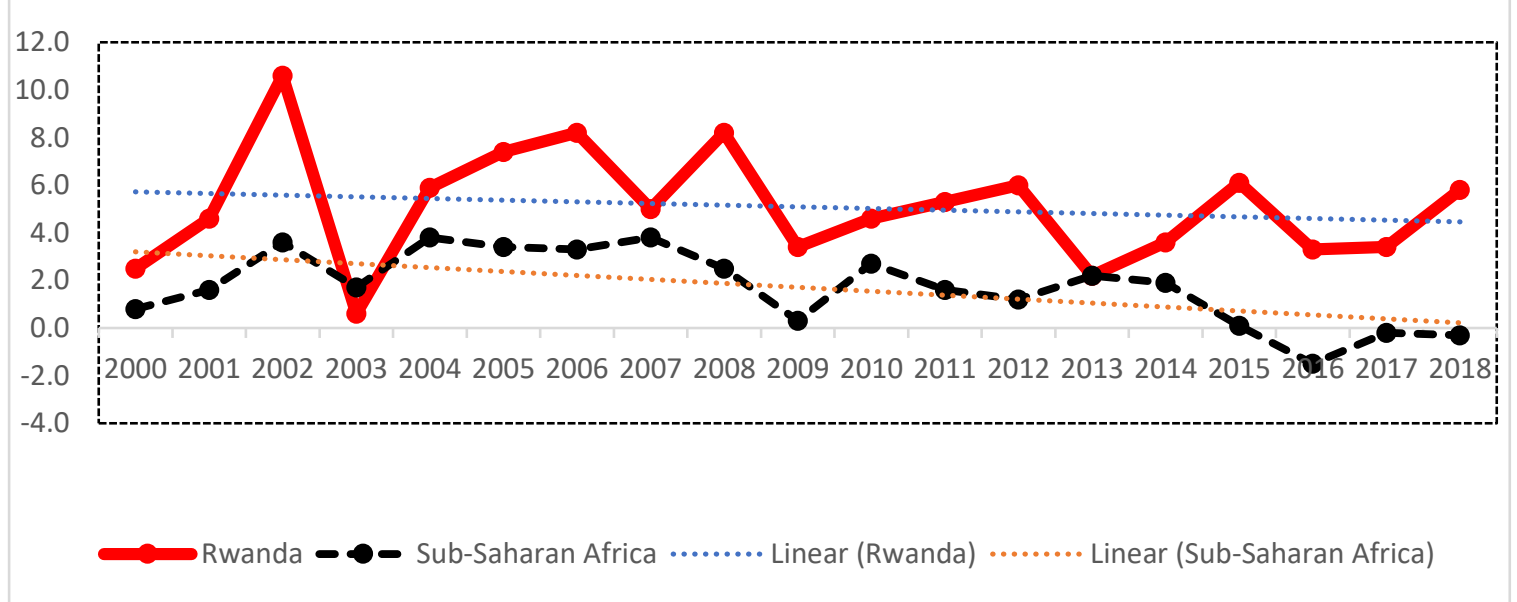

Source: World Bank (WDI)

\section{Building a market economy}

The percentage of population in waged non-farm work as their main occupation increased from $7 \%$ in 2000/2001 (EICV 1) to nearly $21 \%$ in 2016/17 (EICV 5). If we include 'independent' non-farm work (mostly 'household enterprises') it increased from $11 \%$ in $2000 / 1$ to $30 \%$ in $2016 / 17$ Men are significantly more likely than women to be employed in non-farm work, $42 \%$ of men compared with $19 \%$ of women in 2016/17. 
However, while there has been a noticeable shift in the proportion of the Rwandan labour force in non-farm employment, much of it is in the informal sector'. with only $8 \%$ of women and $12 \%$ of men employed in the formal sector (RLFS 2018). Furthermore, while official unemployment is $14 \%$, if discouraged workers and those potentially available to work are included it stands at $48 \%$ with, in addition. $32 \%$ of employed workers being underemployed (RLFS 2018).

To fund the social changes to which it has committed itself, the Government needs GDP growth. The economy is certainly growing (Figures 2 and 3 above). The growth rate averaged $5.1 \% \%$ per annum over the 19-year period 2000-2018 and 4.4\% between 2012 and 2018. However, in 2012 it was estimated that growth of $12 \%$ per year would be required to achieve Vision 2020; the current discussions of Vision 2050 put the 2020 target off to 2035 and talk about sustained growth of over 10\% per year (World Bank Group and Government of Rwanda 2019).

Overall there has been a movement away from raw agricultural products since 1996, manufactured goods are increasing as a proportion of exports - from less than $2 \%$ in 1996 to over $12 \%$ in 2016, and the Service sector has risen as a percentage of GDP from less than $40 \%$ at the start of the century to over 50 per cent at the end of its second decade. Exports are rising, but the serious imbalance between imports and exports is a problem; on the whole imports exceed exports by more than $10 \%$ of GDP in virtually every year of this century. This increases the need for foreign currency to redress the balance, and Rwanda has tried a variety of sources. Foreign Direct Investment (FDI), for example, has shown a considerable increase over time as a share of GDP, from less than $1 \%$ in 2000 to $3 \%$ or a little more at the end of the second decade. However, FDI still forms not much more than $3 \%$ of the available annual resources, and the modest growth in trade and industry as a whole, which is what foreign investment funds, has been in sectors such as telecommunications, retail and 
construction rather than the production of goods and services; agricultural produce and minerals still make up the bulk of the exports. Remittances also bring a little money into the country, important at the level of the families receiving it but not a great deal in national terms. Tourism is a growing source of outside funds, from less than 5\% of GDP in 2006 to more than $7 \%$ in 2018; again these figures are not large enough to make much of a difference (Figure 4), but the growth in the sector has at least created much-needed employment.

\section{Figure 4: Economic and Political Rents and Government Revenues (\% GDP)}

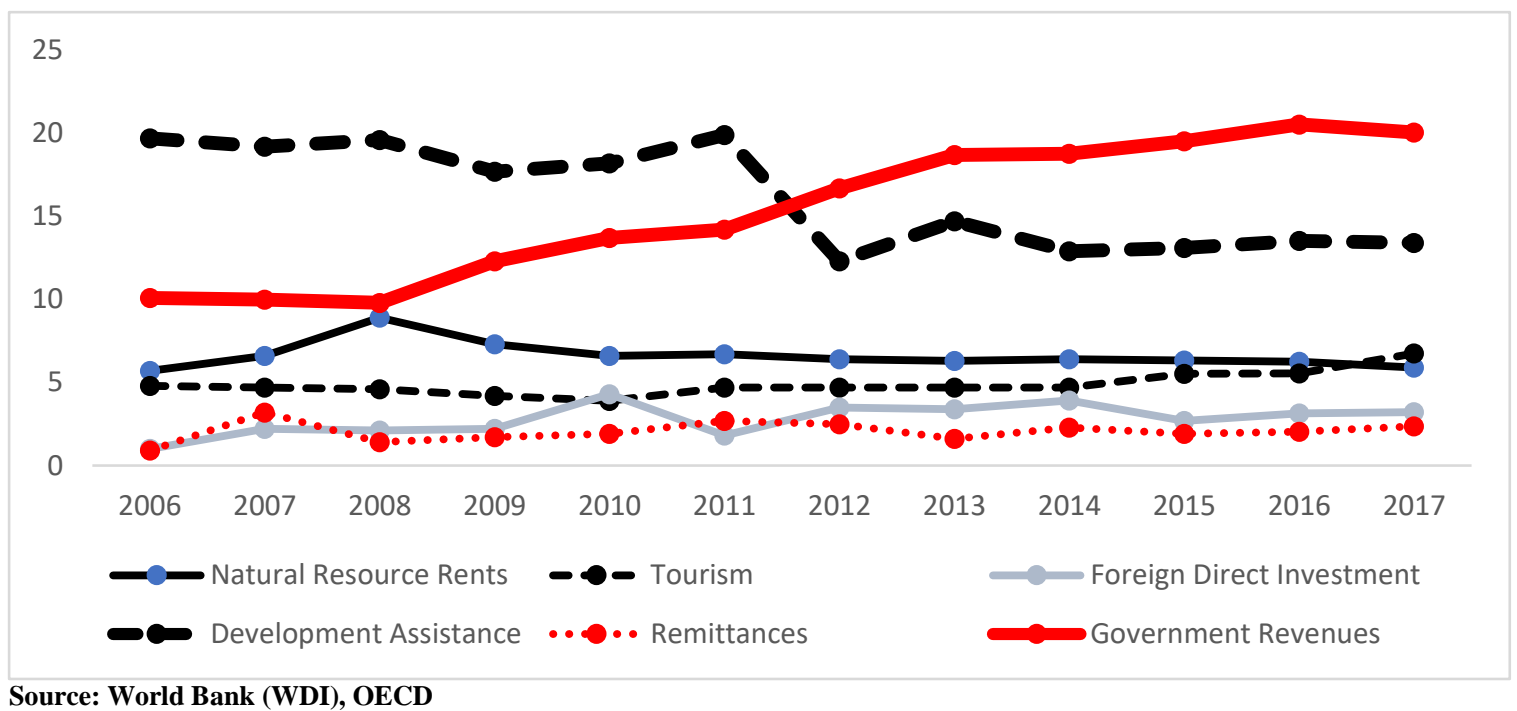

Overall, therefore, Rwanda is moving in the direction that it needs to take in order for its population to be economically secure, but progress is slow and too few jobs are being created to absorb school leavers coming onto the labour market, let alone absorb the unemployed and under employed labour force..

Government's domestic revenues have doubled since 2006 (Figure 4), from around 10\% of GDP to $20 \%$ (not including natural resource rents, which contribute a fairly steady $6 \%$ each year). However, the balancing term is still developmental aid, although it has declined over the period from $20 \%$ of GDP in 2006 to about $13 \%$ in 2017 . However, revenue growth will take a long time to replace aid at this pace, and what the aid buys is crucial to Rwanda's political settlement. and the promotion of Social Inclusion and to Empowerment. 


\section{Welfare and the Social Wage}

\section{Poverty alleviation and social protection}

One urgent reason for seeking economic growth was to generate resource which could be used to narrow income inequality, lift people out of poverty and increase economic security and social inclusion. Here Rwanda would claim substantial success, though there is still much to be done. Using the World Bank absolute poverty line, poverty ( $\$ 1.95$ per day in 'international dollars' - i.e. correcting for purchasing power). The proportion of the population in poverty fell from $77 \%$ in $2001 / 2$ to $55.5 \%$ in $2016 / 7$. Based on the national poverty line (lack of the ability to purchase the basket of essential goods) poverty has fallen from $60 \%$ in $2000 / 1$ to $39 \%$ in $2016 / 17$, and extreme poverty ( inability to feed the household) fell from $40 \%$ to $16.3 \%$, meeting the 2015 Millennium Development Goals (MDG) target for extreme poverty but not for poverty as a whole. There was, however, no decline in poverty between 2013/4 and 2016/7 and there has been some controversy as to whether poverty really fell between 2010/11 and 2014/15. Another MDG target was the malnourishment of children. The proportion of underweight children is now less than a third of what it was in 1992 and the MDG target of 14.5\% had been reached by 2010/11. However, stunting (being under height for age), which was not an MDG target but is a Sustainable Development Goal, remains a serious problem which limits people's potential to develop capabilities in the Empowerment quadrant of Figure 1 because it is associated with the risk of irreversible cognitive impairment. Nearly half of Rwandan children under 5 were diagnosed as stunted in 2000, and in 2015 the figure was still almost 38\% (RDHS 2014/15).

Furthermore, a survey in 2015 (CFSVS) found that only 40\% of households were fully food secure; $40 \%$ were only marginally food secure, $16.8 \%$ food insecure and $3.2 \%$ severely food insecure. 
A reduction in the percentage in poverty does not necessarily show a reduction in inequalities when an absolute poverty line is used - people can move out of poverty while inequalities become more extreme. Rwanda's GINI coefficient for 2000 was 48.5, rising to 52 in 2005 but gradually dropping to 43.7 by 2016 (WDI). This is higher than other East African countries, but not by a great deal, and it appears to have remained steady or declined over time. However, there are suggestions that the GINI may be a poor estimate of the real inequalities experienced by some demographic groups (see, e.g., Ormert 2018): a better but more cumbersome approach might be to look at access to a wide range of particular goods and services.

Another major component of economic security is dealing in a socially inclusive manner with risks across the life-course. This implies a health service (discussed below) and a social security system. Rwanda's social security system works through a devolved decision-making process (Ubudehe) by which a subvention for the alleviation of poverty is distributed locally in the form of subsidies for healthcare and schooling costs where needed plus paid work on public projects wherever possible or direct financial support where no-one in the household can work. There is also a contributory retirement pension scheme for those in non-farm employment. Beyond this, emergencies are funded from personal savings or loans, and the government has encouraged local cooperative savings banks - the Umurenge Sacco scheme (AFI 2014)- and regulates their operation; these make it easier for people to save relatively small amounts safely to cover relatively small emergencies. In 2016 only $12 \%$ of the adult population did not save at all during the year (Murenzi 2016), down from 29\% in 2012. Thirteen per cent saved with a bank (and perhaps also elsewhere), 36\% with another registered institution such as a SACCO, $27 \%$ as part of an informal savings group ('Tontine') and $10 \%$ 'at home' ('banking' with another family member). However, the main driver of saving was for 'planned emergencies' - over $70 \%$ of those who saved did so to cover 
expenses when times were hard, which leaves little for unplanned emergencies such as major health problems in the family.

\section{Healthcare}

Access to healthcare is critical for QoL, adding to households' economic security and ensuring children can meet their full potential. Rwanda is reasonably well provided by African standards with public health infrastructure (clean water and reasonably safe disposal of effluent): provision has increased steadily over the years (EIC1V). General health has improved: life expectancy has risen from 47.6 years in 2000 to 65 in 2017 for men and from 49.2 to 69.2 for women (WDI). The infant mortality rate declined from 107.7 in 2000 to 28.9 in $2014 / 5$ and the child mortality rate from 181.4 to 37.9 . Maternal mortality also declined over the period, from 1071per 100,000 births in 2000 to 210 in 2014/15. AIDS is being kept in check the prevalence rate has been stable since it was first accurately estimated in Rwanda, in 2005; the current prevalence rate is about 3\% (Nsanzimana 2019). Access to antiretroviral drugs was 95\% of those eligible for treatment in 2014 (RDHS) and is currently estimated at $82.7 \%$ (RBC 2017). Measles immunisation has reached $98 \%$ of children in their first two years, as compared with a sub-Saharan average of $73 \%$, and general vaccination rates rose from $75 \%$ in 2005 to $92 \%$ in $2014 / 15$ (RDHS).

Access to basic healthcare has provided nation-wide since 2005 by the mutuelle de santé insurance scheme, which provides a basic package at all levels of health care. There is a graduated membership fee based on Ubudehe category, with the poorest exempt from payment, and a small user fee (10\% of the cost) for treatment and medicines. Membership of the scheme has been compulsory since 2007 for those not covered by other schemes. However, in $2016 / 17$ only $70 \%$ of households were members, with a further $5 \%$ being covered by other health insurance (EICV5). Although the fee is per person (including 
children over 6 months), all members of the household have to be insured for services to be provided.

\section{Educational provision}

Education is important for empowerment, opening a route to new capabilities and ways out of poverty, and equitable access to it is important for social inclusion. The Government has funded fee-free education up to the end of primary school since 2003, and-lower secondary school ('9-year basic') since 2009 and , and it was extended to-'12-year basic' (end of senor

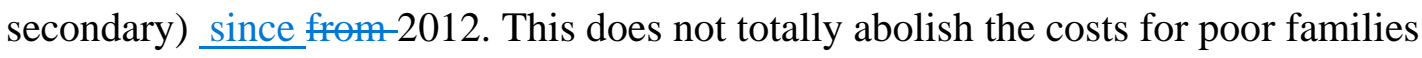
(Williams et al 2015) but does reduce them substantially. Net primary-school attendance stood at about 74\% in 2000 and has hovered between $86 \%$ and $90 \%$ since 2005/6 (EICV). However, there are high repetition and drop-out rates, and our best estimate of the proportion who go through primary school and complete at the right age is 17\% (Abbott et al 2015). Around $50 \%$ complete primary by age 19 , the age at which young people should have completed senior secondary.

\section{Figure 5: Primary and secondary school net attendance and secondary school gross}

\section{attendance $(\%), 1990-2017$}

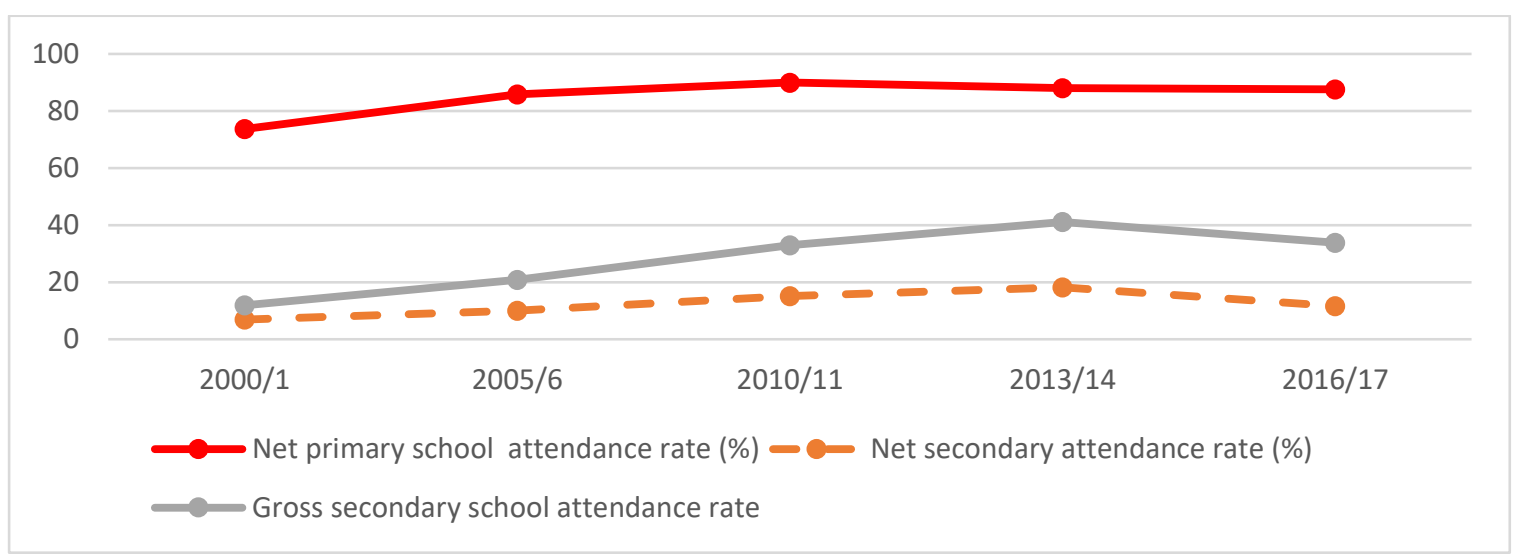

Source: EICV

In order to build a middle class engaged in decent non-farm work and to attract investment, secondary and even tertiary education are important. Both the gross attendance rate (all 
children attending irrespective of age, as a proportion of children of secondary-school age) and the net rate are low (Figure 5). The expansion at secondary level (and, subsequently, tertiary) is powered by the extension of fee-free secondary schooling and has declined in recent years. This may be because of the difficulty educated young people have experience in getting decent employment.

Serious doubts have been raised about the quality of education provision, from primary schooling upwards. The Government 'scores points' with its populace and with the international community by expanding educational opportunities and getting children/young people to enrol, but there is strong survey evidence that the education is not very good (DeStefano and Ralaingita 2012, ICAI 2012, Upper Quartile 2015). This is true across much of Africa, but in Rwanda a specific additional factor is the shift from French to English as medium of instruction without a corresponding shift in teachers' linguistic competence.

Rwanda has also paid little attention until recently to providing pre-school education and care despite its known benefits (Abbott and D’ Ambruoso 2019). Adult basic education has also received little investment despite the known benefits of education for poverty reduction and improving people's QoL and the Government's own target of eliminating illiteracy by 2018 (Rwandan Ministry of Education 2014). Little progress has been made in reducing the illiteracy rate over the last 15 years and a third of adults do not have basic capabilities in reading and writing (Abbott 2019).

\section{Cohesion, empowerment and governance}

The quadrants of Economic Security and Social Inclusion are explicit goals of Rwandan government policy - making life better for citizens, lifting people out of poverty, creating decent jobs and a middle class while at the same time ensuring that improvements are shared inclusively and equitably. The underlying principle of ensuring that genocide does not happen again entails creating a unified Rwanda in which everyone has some sense of 
ownership. This section of the chapter turns away from economic provision and the social wage to look at the other side of Rwanda's social engineering - issues of Social Cohesion, the creating of new Rwandans for a new Rwanda, and the sociopolitics of Empowerment.

The social infrastructure for these quadrants has already been considered in the more economistic discussions above - economic security, including insurance against expensive life-stages and unforeseen emergencies. Education is also important for empowerment and equal access to it is part of social inclusion, which is in turn a prerequisite for social cohesion, and adequate heath is a prerequisite for empowerment and the ability to acquire and display competencies. Clean government and the rule of law are important in all quadrants.

\section{The quality of governance}

Rwanda is well policed and has relatively little crime. The administration of the legal system is seen as fair, the courts have the trust of a remarkably high proportion of the population (WVS6) and while, the judges are government-appointed, it is possible to take the government to court and win. Elections have generally been deemed fair 'at point of delivery' by international observers, though the size of the majority in presidential elections reinforces our belief that opposition is systemically inhibited. There are limits set in the Constitution on the extent to which any one party can dominate the Government in terms of ministerial appointments, and the United Nations Conventions on Human Rights have been adopted into Rwandan law. Gender equality is enshrined in the Constitution, a quota system ensures that women are strongly represented in the Parliament, the Cabinet and the civil service, and there is a Minister for Gender and Family Promotion and a Gender Monitoring Office. Monetary corruption has been more or less eliminated, and even Ministers go to jail when convicted of it.

Rwanda's performance scores reasonably highly on the Worldwide Governance Indicators, the most frequently used of the international measures of quality of governance (Figure 6). It 
does very well on control of corruption, scores above the world average on regulatory quality, the rule of law and government effectiveness and shows a reasonably adequate performance on political stability and the control of violence but with a slower rate of improvement over time.

\section{Figure 6: Worldwide Governance Indicators for Rwanda 2000-2017 (percentile rank)}

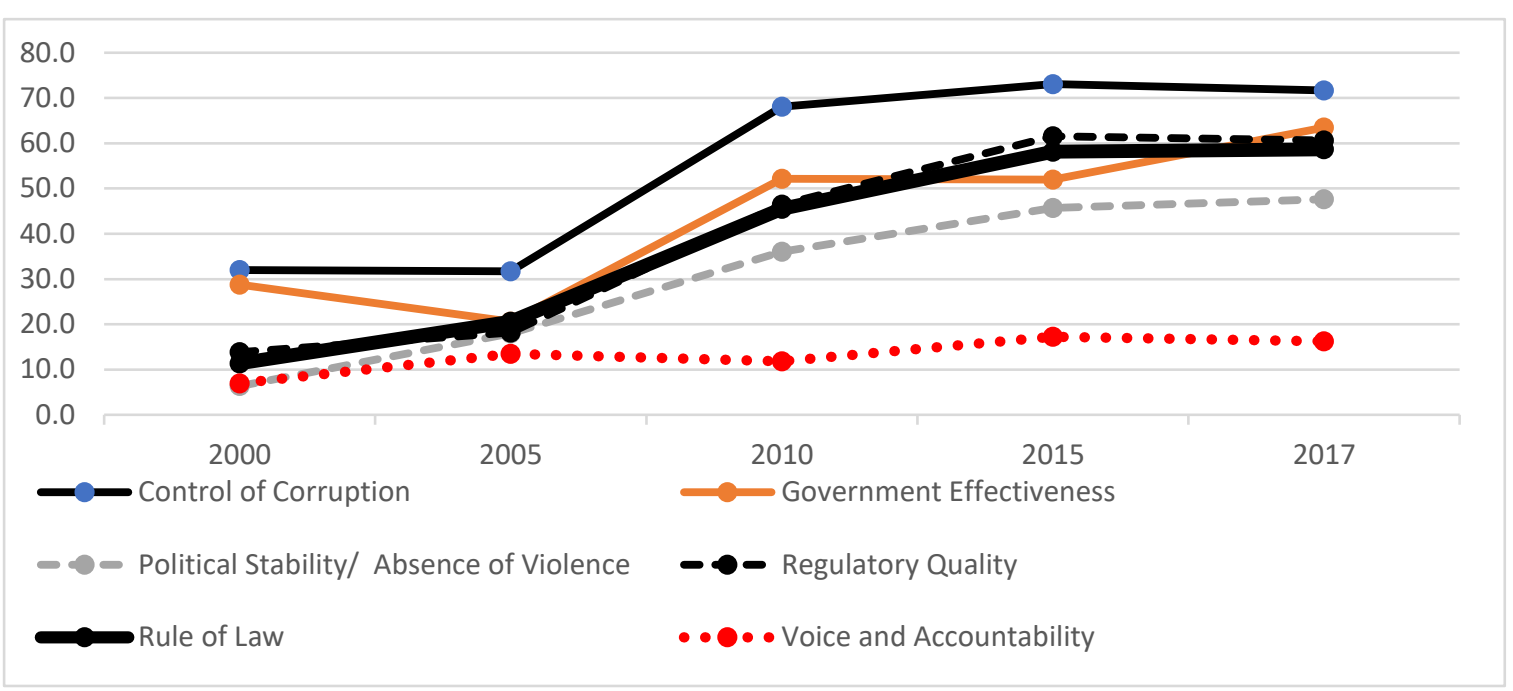

Source: World Bank (WWGI)

These would appear to be favourable conditions for QoL, expressing both social cohesion equal treatment under the law - and the empowerment of citizens. However, the score on 'voice and accountability' - the freedom to criticise government policy and the transparency of government actions - is very substantially below the world average. This variable can be used as a proxy measure of democracy: free and fair elections and basic civil and political rights are usually seen as the minimum for a government to be seen as democratic (i.e. polyarchic). Rwanda does not encourage pluralistic politics. The Rwandan social order is underpinned by a commitment to non-adversarial discussion, backed by control of ideologies and the mechanisms for their dissemination. 'Dialogue and consensus' is written into the Constitution and is espoused in both national and local politics. This is discussed further below. 


\section{Consensus, cohesion and control of the norms of thought}

Rwanda has the trappings and rhetoric of a democracy, but its Government has stressed and indeed enforced consensus in decision making, local responsibility and personal commitment to the country's success, both in its ideology and in the structures which have been put in place. While it has recruited its citizens as agents of change, what it has not done yet is to empower them to take personal or collective responsibility for planning and debating the country's policies and goals. At the national level genuine multi-party competition for political power is rendered difficult by laws which ban divisive ideology (fuzzily defined), a system of party registration which makes it difficult for those who oppose RPF policies to stand for election, and control of the media exerted by government and/or 'self-imposed' by editors and reporters. Civil society organisations which in a more democratic society might be lobbying government or trying to influence public opinion are also subject to registration and often tend to restrict themselves to the role of service provider.

The institutionalised requirement for value consensus goes down to the level of villages, households and individuals. Consensus about values is manufactured in Ingando (solidarity camps/retreats where 'Rwandan values' are inculcated or reinvigorated), Itorero (civic education sessions) and the discussions which follow the monthly Umuganda (volunteer labour on local infrastructure). These institutions help to bind citizens into the collectivity of the nation. Active citizenship is a strong part of the message; for example, Umuganda labour is required by law but also characterised in Rwandan rhetoric as the mobilisation of the population in the service of the nation (though it is not clear that this is always how citizens actually think about it) Imighigo is another example - the 'performance contracts' whereby the implementation of targets for the year are agreed at all levels from the household and the employee to the district administration and the ministries. 
Rwanda's policy is to decentralise where possible, ostensibly to give local people more faith in decisions and advice which come from people who know them well rather than from some remote bureaucrat but constituting an effective way of encouraging citizens to blame local government for poor service delivery rather than central government policy.. Decentralisation begins with the Districts, responsible for service delivery held to account by performance contracts (Imihigo), which deflects attention from central government to local performance Ubudehe works at the village level (the smallest of the administrative divisions) and determines who needs social security support; it thereby diverts any dissatisfaction from the centre to the locality (Abbott et al 2014).

At the same time, some of the mechanisms for improving QoL move control from the periphery to the centre. Because the District 'contracts' with Government the targets it will fulfil in the next year, the targets are those set centrally by Government; decision-making is top-down. The process whereby Districts determine what shall be grown by households that want the benefits of the CIP effectively allows the state to determine the use of household land (Ansoms and Cioffo 2016). Key organisations - 'National Councils' - to protect the rights of vulnerable groups (women, youths (which for this purpose means people between the ages of 18 and 35 in Rwanda), handicapped people) were set up by the Government as part of its commitment to social inclusion, but their effect is to 'crowd out' genuinely independent NGOs that might have fulfilled this function and ensures adherence to Government policies rather than facilitating grass-roots advocacy. (Abbott et al 2016).

\section{Capturing the discourse}

The Dialogue and Consensus approach 'captures the discourse' so that the rightness of decisions 'stands to reason'. Within a given discourse there are propositions which people automatically support - they 'stand to reason' - and against which it is difficult to argue without appearing perverse. What can be more natural, for example, than that your 
neighbours who know you, rather than some faceless official should be responsible for deciding whether you need social protection/support and what form is appropriate? What could be more natural than that the Abunzi, as elected local 'consensus brokers' in e.g. land disputes, offer you a compromise even if the letter of the law would give you a better outcome? The land consolidation policy is justified by its 'obvious' efficiency, which pushes resistance to the difficult extreme of opposing rationalisation and therefore standing against economic growth. What could possibly be wrong about a caring state setting up national organisations to protect the interests of those whose voice is seldom heard? It stands to reason that people will work on the roads and drainage, because they live in the village and know it is expected. In all these cases it is not a question of what the Government wants you to do; rather, it is assumed without debate that you yourself will want to do it.

There is nothing unusual in this process of capture - all states which depend on the support of the governed use it and all moral arguments depend on it - but its role in Rwanda should be noted. At the community level, therefore, part of the force of 'community involvement' is based in cultural norms but it also owes something to the deliberate shaping of the discourse. Government policies enjoy hegemony: they allow only one way in which to think. An example would be the spirit of 'working for Rwanda' which has been taken up and fostered by the Government as a way of ensuring that a decent life is provided and that QoL is improved. In this they are going with the current of a society in which family and community are part of one's identity. Richer members of the family, established in good jobs, will expect to pay a share of expenses towards other family members' marriages, childbirth, education, sickness and funeral expenses. The middle class not infrequently spend part of their salaries sponsoring orphans and street children through school or university or even adopting the orphans themselves. One important reason for parents owning land is to be able to give their children land on which to build a house. (Few can now do this because of the 
shortage of land and the restriction on splitting plots which are less than a hectare in area, but some parents see investing in their children's education as equivalent - see Abbott et al 2012.) Responsibility becomes everyone's, not just the state's, and this is entirely typical of the Rwandan style of government.

\section{SUBJECTIVE QUALITY OF LIFE AND WHAT THE PEOPLE WANT}

Finally, how do the Rwandans feel about their lives? The World Happiness Reports present a data series from 2011 to 2018 for 156 countries (sometimes one or two more) on the Cantrell's Ladder question used by the Gallup World Poll, which asks respondents to place their lives somewhere on a continuum from 0 (the worst possible) to 10 (the best possible). On this measure Rwanda is consistently near the bottom of the world, on average in $152^{\text {nd }}$ place (once $151^{\text {st }}$ but once $154^{\text {th }}$ ). Their average scores range from 3.33 to 3.72 over the period, with at best only a very slight increase over time. Putting this in context, in 2018 only four countries ranked lower - neighbouring Tanzania (3.23), Afghanistan (3.20), the Central African Republic (3.08) and South Sudan (2.86). The top seven countries, mostly Scandinavian, scored in the range 7.34-7.77. So, with everything that has been achieved or attempted, the population of Rwanda still do not regard their QoL as improving significantly. (They are not out of line with other sub-Saharan countries in this respect, however. The highest-ranking sub-Saharan country in 2018 was Nigeria $\left(85^{\text {th }}\right.$ - below the half-way mark), followed by Ghana at $98^{\text {th }}$ ).

Respondents to the 2013 wave of the World Values Survey (WVS) were asked what the aims of the country should be for the next ten years, and three quarters of them nominated economic growth (69\% as first choice) and about $40 \%$ nominated strong defence forces (15\% as first choice) - see Table 1 for first and second choices. It would be a mistake, however, to suppose that Rwandans care only for their material wellbeing and do not particularly worry 
whether they are empowered politically. Twelve per cent (one person in eight) said 'people having more say' was the most important choice for the nation, and over half placed it first or second. Asked about what affected them personally, three quarters nominate 'maintaining order in the nation' (rising to $86.5 \%$ if we include second choices) and two thirds nominated 'fighting rising prices'. Fourteen per cent (one person in seven) nominated 'giving people more say' as first choice, and if we include second choices the figure rises to about $35 \%$. Similarly, not much more than one person in a hundred noted 'the protection of free speech' as the most important personal factor but including second choices raises the count to $14 \%$. It is clear that a significant minority are concerned with rights, despite the presence of economic or defence options on the lists, and while we may conclude that economic concerns are the most salient we may not conclude that political rights are unimportant, despite the extent of Rwanda's ideological control. This pattern is not uncommon in countries which are in developmental transformation (Teti et al 2019).

Table 1: The two most important aims for country and respondent, in Wave 6 of the World Values Survey (\%)

\section{Aims for the country}

\begin{tabular}{|c|c|c|c|c|c|c|c|}
\hline & 1st & 2nd & $\begin{array}{l}1^{\text {st }} \text { or } \\
\text { 2nd }\end{array}$ & & 1st & 2nd & $\begin{array}{l}1^{\text {st }} \text { or } \\
\text { 2nd }\end{array}$ \\
\hline $\begin{array}{l}\text { High levels of economic } \\
\text { growth }\end{array}$ & 69.1 & 6.3 & 75.4 & $\begin{array}{l}\text { Maintaining order in } \\
\text { the nation }\end{array}$ & 73.9 & 12.6 & 86.5 \\
\hline Strong defence forces & 15.2 & 24.5 & 39.7 & Fighting rising prices & 10.5 & 54.3 & 64.8 \\
\hline \multirow[t]{2}{*}{ People having more say } & 12.0 & 39.7 & 51.7 & $\begin{array}{l}\text { Giving people more } \\
\text { say }\end{array}$ & 14.4 & 20.3 & 34.7 \\
\hline & & & & Protecting free speech & 1.2 & 12.8 & 14.0 \\
\hline
\end{tabular}

Source: WVS6 


\section{DISCUSSION: ENGINEERING THE QUALITY OF LIFE}

Rwanda has been presented as a case study of recovery from disaster and the re-engineering of a shattered society - planning for social quality. Two main areas of action have been identified - the economic and the discursive. These two strands are involved in all four quadrants of the Decent Society Model but often express different aspects of them. Mostly the concern of the chapter is with what facilitates QoL and whether the Government has succeeded in achieving it. However, state control of 'hearts and minds' - the discourse, what people believe, what they take for granted and what they value - may also have negative consequences, for empowerment and for QoL.

\section{Economic security and social inclusion}

There is no doubt that social provision has improved in Rwanda over the past twenty years and continues to do so. Housing and health provision have improved steadily, communication links by radio, telephone and/or the internet cover virtually all the country, fee-free education is available from age 7 to completion of secondary schooling, health is covered by an insurance scheme, HIV, malaria, measles and tuberculosis are kept under control and there is a social security net for the poorest and a pension scheme for those in formal employment. It is important to government that everyone share in these benefits. Outright poverty and therefore exclusion from the mainstream is still high and raising people out of it is one of the government's priorities.

There is evidence, however, that economic improvement is stalling, with aid reducing, FDI levelling off and the reduction of poverty rates slowing down. The problem is that welfare 
provisions are mostly not self-funding and collectively they are still beyond what can be paid for out of taxes and other Government revenues.

The Rwandan state is ingenious in its use of the decentralisation principle to pass on unaffordable costs to local volunteers and at drawing on community spirit and 'sensitising' people to what 'a good Rwandan' will naturally do, with the state providing (or eliciting from donors) materials with which to do it. When schools had to be expanded to meet the needs of fully inclusive education or to expand pre-school provision, for example, it was seen as natural by the parents themselves that they would build the extra classrooms.

To improve the diet of children and mothers-to-be, the Government does provide a universal supply of some supplements to pregnant women and targeted supplements and even tinned food to children who are malnourished (see RDHS); there is also regular weighing of all young children to make certain that they are not malnourished. However, the 'mainstream' Rwandan solution has involved

- sensitisation of mothers to the importance of a varied diet for young children, through Community Health Workers (see below),

- encouraging Rwandan women to make the land around their houses into kitchen gardens where greens and root vegetables can be grown for the table (with perhaps a surplus for sharing or sale), and

- providing a cow (donor-funded) to poorer households who could demonstrate they had sufficient land to feed it, which produced milk for the family and perhaps again a surplus to share or for sale (and calves from the cows were supposed to be passed on to other poor households and extend the network).

Primary health care reaches out to the villages because of elected volunteer Community Health Workers, who are compensated for their time - partly in the form of provision for a cooperative to cover their living costs (perhaps a gift or loan of land by the state). 
The battle to build a sustainable economy has not yet been won at the level of Economic Security across the life-course Families with children under 15, lone mothers and elderly people, especially women (see Sabates-Wheeler et al 2018), remain at greater risk of poverty (and by 'poverty' here we mean not having enough to eat). The Rwandan Government has taken several steps to regulate inequalities between genders, including legislating for the inheritance of land by daughters and by women in officially registered marriages as well as by men (Abbott et al 2018), but economic security across the life course remains an issue, especially for girls and women.

\section{Social cohesion and political empowerment}

An overwhelming imperative in Rwandan politics, sometimes explicit but always tacitly present, has been to create new citizens, replacing sectional identity with national identity 'we are all Rwandans now'. To further this aim, strong measures of social control have grown up which reach down into the villages and even households (see e.g. Purdeková 2011). The institutions through which the process works are structured to create consent to state policies and thus to present and reinforce state ideology as expressing the will of the people, or at least what the will of the people should be (Abbott et al 2014) .

Key to the institutional implementation of a 'one nation' rhetoric is the notion that government shall appear to be carried out, at least in part, not by remote central ministries and agencies but by people known in the community. The particular form that is used has particular effects, however. Dispute resolution, and community action to 'police' disapproved behaviour such as failing to send children to school, would normally take place in the first instance through action by the elected village leaders or by discussion in 'councils' (generally ad hoc meetings) of family or neighbours. The Abunzi - volunteer mediators, also locally 
selected - have as their task the production of consensual solutions to disputes before and instead of putting them to the courts - a prime example of the 'dialogue and consensus' principle (Abbott et al 2018) which weakens the authority of the law, which becomes just the starting point for negotiation.

The monthly Umuganda community labour is the most obvious of the 'ideological institutions' at village level. The work sessions of Umuganda are normally followed by meetings which act as the interface between the local and the central. Government policy is promulgated and explained by local leaders and information about health, child-rearing and the avoidance of AIDS is delivered by Community Health Workers. The format of Umuganda meetings lends itself to top-down sensitisation rather than bottom-up discussion (Hasselkog 2015: 161-2). The consensus which is reached is the Government's consensus, and partnership very often means a commitment to implementing the Government's policies. The Women's National Council and National Council of Youth reach down to the lowest level of organisation and are in a position to carry the grassroots views up the chain to central government, but in practice messages go down but there is little scope for messages to go back up. In other words, they act as agents of hegemony rather than political empowerment. Finally, 'dialogue and consensus' has a different understanding of politics from multi-party democracy. At a fundamental level Rwanda's stance makes radical opposition - i.e. having a different vision of the country's future - broadly unthinkable: how can you dissent from what has been established already as a consensus? At the level of national politics there can indeed be enough dissent or difference to allow a competing party to constitute itself (though only the RPF has adequate funding for political campaigns), but the broad principles constitute the society, so that dissent from them can be read as an attack on Rwandan unity in the interests of some faction. "Simply put, in Rwanda opposition is not tolerated" (Friedman 2012: 268). 


\section{CONCLUSION}

The case of Rwanda illustrates what can happen when a government sets out to engineer a decent life for citizens. In economic terms, the political settlement which forms the implicit contract between government and citizenry is one of developmental neopatrimonialism, with accessible resources ploughed back into QoL and people's capacities rather than into shorterterm rewards for supporters and buying off opponents. This can readily be seen as a sustained attempt to create Social Quality through investment in infrastructure and a social wage..

To debate here whether these are the tactics of a party which wishes to remain in power or an altruistic concern for wellbeing is a pointless exercise; there are always elements of both in any government's planning. For example, it is equally true of English and French employers during the earlier phases of the industrial revolution (a) that they built model housing for their workers and gave them access to healthcare and education out of a philanthropic/Christian desire to 'do the decent thing', and (b) that they quite consciously offered these benefits to reduce labour mobility, improve the health and therefore the efficiency of the workforce and ensure a succession of exploitable labour - see e.g. Donzelot (1977). For citizens, the improvement in the quality of life is the same whatever mix of motives may underlie it. Immediate targets in Rwanda are the alleviation of poor QoL and raising people out of poverty, which in turn may mean reshaping the whole of the society. It has meant working towards a predominantly waged economy, extending the role of the market, increasing and 'industrialising' agriculture, building industries and services which can contribute to the resourcing of the population but also generate tax revenues to fund public provision, and the funding of accessible healthcare, plus education and training to upgrade the workforce is and attract investment. Affordable access to healthcare and education and a welfare safety net for the sick, disabled and elderly form a 'social wage' which contributes to QoL, and they 
become part of the visible benefit of the political settlement. They provide social inclusion for the poor and needy by empowering people to (continue to) take part in the normal activities of the society and to exercise their capabilities.

All of this has been attempted, and it has had its effect, but the process will clearly take longer to complete than had originally been hoped. Global economic conditions have not been favourable, and while Rwanda's economy is growing, it is not yet growing fast enough to take over the burden of supporting education and healthcare (or indeed agriculture, infrastructure and many other things) without dependence on international development assistance. This is a problem, given that willingness to give aid has been tending to decline in recent years.

Social inclusion is particularly important to Rwanda because of the Genocide. If economic and social progress could occur fast enough, then the new generation would consist not of fractions competing for scarce resource but of people embracing a national identity. Rwandan social engineering depends on a re-education of the population to see Rwanda as a single tribe or community, not an amalgam; the Government manipulates the collective consensus to ensure that divisive ideologies cannot emerge again. They may be right that this is necessary; it is clear even from survey research that Rwanda's internal divisions have not gone away. A significant proportion of Rwandans still fear civil disorder (see Table 1) and a majority think that there are still cleavages between groups. It is unclear what will happen if the political settlement is broken and social progress dries up for lack of financial underpinning.

Underneath the practical and economic problems lies the deeper problem of the amount of control and state involvement entailed by the combination of economic adversity, a deepfelt need for close social cohesion and the totalising way in which the Government is trying to build a new kind of citizen. 'Dialogue and consensus' is put forward as an 
African solution to political problems, a non-adversarial approach to taking decisions which does not leave space for feeling disadvantaged or discriminated against, leading to a generation which regards dedication to the future of Rwanda as a foundational norm against which resistance is not only unacceptable but largely unthinkable. However, the consensus which is Rwanda is largely produced at the centre and conveyed to the grass roots for implementation. Controlling both actions and ideology 'for their own good' was undoubtedly an effective way to re-establish a broken Rwanda and start the healing process, but it is a powerful horse with a will of its own and one that may prove very difficult to dismount. The evidence of attitude survey data is that the economic situation is the most salient and widespread issue for most people but that politics is not dead and there is also a substantial desire for improvement of political rights. Educating the population, in Western style, to question taken-for-granted practices and espouse new ways of doing things may be what is needed for Rwanda to join the ranks of middle-income market economies, but it also leads to successive generations who may not accept that leaders and the Government know best what is good for their well-being.

\section{REFERENCES}

\section{Sources of data}

CFSVS - Comprehensive Food Security and Vulnerability Survey:

http://www.statistics.gov.rw/ datasource/comprehensive-food-security-and-vulnerabilityand-nutrition-analysis-survey-cfsva

EICV1, 2, 3, 4, 5 - Integrated Household and Living Conditions Surveys: http://statistics.gov.rw/ datasource/integrated-household-living-conditions-survey-eicv

\section{OECD:}

- Government revenues: https://stats.oecd.org/Index.aspx?datasetcode=RS_GBL\#

- Development aid: https://stats.oecd.org/qwids/ 
RDHS - Rwandan Demographic and Health Survey (periodically since 1992): http://www. $\underline{\text { statistics.gov.rw/datasource/demographic-and-health-survey-dhs }}$

RLFS 2018 - Rwandan Labour Force Survey: http://www.statistics.gov.rw/datasource/ $\underline{\text { labour-force-survey-0 }}$

World Bank:

- World Development Indicators: https://databank.worldbank.org/data/ databases.aspx? pagenumber $=1$

- Worldwide Governance Indicators: https://datacatalog.worldbank.org/dataset/worldwidegovernance-indicators

World Happiness Reports (2012-2019): http://worldhappinessreport/download/ WVS - World Values Survey (Wave 6): http://wvs-online.com/wvs.jp

\section{Other references}

Abbott, P. (2019) The Social Practices Approach to Adult Literacies: How to Stop Failing Adult Learners. Aberdeen: University of Aberdeen.

Abbott, P. and D'Ambruoso, L. (2019). Rwanda case study: Promoting the integrated delivery of early childhood development. Training and Research Support Centre.

Abbott, P and Malunda, D. (2014). The Impact of Agricultural Policy and Budget Allocations on Women Farmers in Rwanda. Kigali: Action Aid.

Abbott, P and Mugisha, R (2016) Mobilising and Managing External Development Assistance for Inclusive Growth: Rwanda Country Case Study. Kigali: IPAR-Rwanda and African Centre for Economic Transformation.

Abbott, P. and Sapsford, R. (2006). Life satisfaction and happiness in post-Soviet Russia and Ukraine. Journal of Happiness Studies 7: 251-287. 
Abbott, P., Rwirahira, J., Musana, S., Kaira, P., Rucogoza, M., Malka, F et al (2012). Raising Productivity and Reducing the Risks of Household Enterprises in Rwanda. Kigali: World Bank/IPAR-Rwanda.

Abbott, P., Mugisha, R. and Lodge, G. (2014). The Constant Search for Solutions through Dialogue and Consensus. Kigali: Senate of the Republic of Rwanda.

Abbott, P., Sapsford, R. and Rwirahira, J. (2015) 'Rwanda's potential to achieve the millennium development goals for education', International Journal of Educational Development 40: 117-125.

Abbott, P., Wallace, C. and Sapsford, R. (2016). The Decent Society: planning for social quality. London: Routledge.

Abbott, P., Mugisha, R. and Sapsford, R. (2018): Women, Land and Empowerment in Rwanda. Journal Of International Development 30,.. doi: 10.1002/Jid.3370

AFI - Alliance for Financial Inclusion (2014). Rwanda's financial inclusion success story: Umurenge Saccos. http://www.afi-global.org/sites/default/files/publications/afi_case_ study_rwanda_finalweb.pdf

Ansoms, A. and Cioffo, G. (2016) The exemplary citizen on the exemplary hill: the production of political subjectivity in contemporary rural Rwanda. Development and Change 47: 6.

Beck, W., van der Maesen, L. and Walker, A. (eds) (1997) The Social Quality of Europe, The Hague: Kluwer Law International.

Beck, W., Thomese, F., van der Maesen, L. and Walker, A. (eds) (2001) Social Quality: A Vision for Europe, The Hague: Kluwer Law International.

Booth, D. and Golooba-Mutebi, F. (2012). Development Patrimonialism? The Case of Rwanda. African Power and Politics Programme. http://www. institutions-africa.org/ publications/research_stream/developmental-patrimonialism 
DeStefano, J. and Ralaingita, W. (2012). Early Grade Reading and Mathematics in Rwanda. Kigali: USAID.

Donzelot, J. (1977) La police des familles. English edition The Policing of Families, translated by R, Hurley, London: Hutchinson, 1979.

Friedman, A. (2012) Kagame's Rwanda: can an authoritarian development model be squared with democracy and human rights? Oregon Review of International Law 14:253-278.

Government of Rwanda (2003) The Constitution of the Republic of Rwanda. Official Gazette $\mathrm{n}^{\circ}$ Special of 4 June 2003.

Government of Rwanda (2015) The Constitution of the Republic of Rwanda of 2003 revised in 2015. Official Gazette $\mathrm{n}^{\circ}$ Special of 24/12/2015.

Hasselkog, M. (2015) Rwandan developmental 'social engineering': what does it imply and how is it displayed? Progress in Developmental Studies 15: 154-169 .

ICAI - Independent Commission for Aid Impact (2012) DfID's Education Programmes in Three East African Countries. London: ICAI. http://www.oecd.org/countries/rwanda/ 50360183.pdf.

Kathiresan, A. (2011). Strategies for Sustainable Crop Intensification in Rwanda: Shifting Focus from Producing Enough to Producing a Surplus. Kigali: Ministry of Agriculture and Animal Resources.

Murenzi, I. (2016) Financial Inclusion Rwanda 2016. Kigali: Access to Finance

Rwanda/Finscope Trust: http://www.statistics.gov.rw/datasource/finscope-survey-2016

Nsanzimana, S (2019) Rwanda population-based HIV impact assessment: key findings.

\section{Rwanda Public Health Bulletin 1: 13-20.}

Ormert, A. (2018) Evidence on inequalities in Rwanda. K4D Helpdesk Report. Brighton: Institute of Development Studies. 
Purdeková, A. (2011) 'Even if I am not here, there are so many eyes': surveillance and state reach in Rwanda. Journal of Modern African Studies 49: 475-497.

RBC - Rwanda Biomedical Centre (2017): Rwanda HIV and AIDS National Strategic Plan 2013-2018 - Extension 2018-2020. Kigali: Ministry of Health.

Rwandan Ministry of Education (2014) Adult Education Policy. Kigali: Republic of Rwanda. Rwandan Ministry of Finance and Economic Planning. (2000) Rwanda Vision 2020. Kigali: Republic of Rwanda.

Sabates-Wheeler, R., Wylde, E., Ulrichs, M., Aboderin, I., Bayisenge, J. and Irambeshya, A. (2018) Population Ageing in Rwanda: Current Needs, Future Projections, and Implications for Policy. Kigali DfID. https://assets.publishing.service.gov.uk/media/ 5b6c063440f0b640a5370011/Implications_of_Demographic_Change_in_Rwanda_FUL

\section{$\underline{\text { L_REPORT.pdf }}$}

Teti , A, Abbott, P. and Cavatorta, F. (2019) Beyond elections: perceptions of democracy in four Arab countries. Democratization 26: 645-666.

Upper Quartile (2015) Final Evaluation Report: Evaluation of Research-Based Aid in Rwandan Education. Edinburgh: Upper Quartile. https://assets.publishing.service.gov.uk/ government/uploads/system/uploads/attachment_data/file/563272/Results-Based-Aid-

\section{$\underline{\text { Rwandan-Education-final-eval.pdf }}$}

van der Maesen, L.J. G. and Walker, A. (eds) (2012) Social Quality: From Theory to Indicators, Basingstoke: Palgrave Macmillan.

Verwimp, P. (2013) Peasants in Power: the political economy of development and genocide in Rwanda. Dordrecht: Springer.

Williams, T., Mupenzi, A. and Abbott, P. (2015) 'Education at Our School is not Free': The Hidden Costs of Fee Free Schooling in Rwanda (2015), Compare. doi: $10.1080 / 03057925.2014 .938611$ 
World Bank (2016). Rwanda Economic Update 9: Rwanda at Work. Kigali: World Bank.

World Bank Group and Government of Rwanda (2019) Future Drivers of Growth in

Rwanda: innovation, integration, aggregation and competition. Washington DC: World Bank. 